\title{
Trichostrongylus retortaeformis (Zeder, 1800) (Nematoda, Trichostrongyloidea) in Lepus europaeus (Pallas, 1778) in southern Brazil
}

\section{Trichostrongylus retortaeformis (Zeder, 1800) (Nematoda, Trichostrongyloidea) em Lepus europaeus (Pallas, 1778) no sul do Brasil}

\author{
Laura Maria Jorge Farias dos Santos ${ }^{1}$; Mariana Mendes ${ }^{1}$; Plínio Aguiar de Oliveira ${ }^{1}$; \\ Fernando Caetano de Oliveira ${ }^{2}$; Nara Amelia da Rosa Farias ${ }^{3}$; Jerônimo Lopes Ruas ${ }^{4 *}$
}

\begin{abstract}
The aim of this study was to evaluate the presence of helminthes parasitizing hares (Lepus europaeus) in southern Brazil. The intestinal tracts of seven hares were opened and the contents were sieved. Among the seven animals in the study, Trichostrongylus retortaeformis parasitized six (85.7\%). This study will be expanded and more animals captured to evaluate the occurrence of other helminthes and to assess whether the high prevalence of $T$. retortaeformis is accurate, as well as to assess the abundance and intensity of parasites. To our knowledge, this is the first record of T.retortaeformis parasitizing $L$. europaeus in southern Brazil.
\end{abstract}

Key words: Helminths. European hare. Exotic mammals. Southern Brazil.

\section{Resumo}

Foi realizado estudo sobre a presença de helmintos em lebres (Lepus europaeus) na região sul do Brasil. Foram capturados sete animais que foram necropsiados e os órgãos (estômago e intestino delgado e grosso) foram abertos e o conteúdo tamisado. Dos sete animais, seis $(85,7 \%)$ estavam parasitados por Trichostrongylus retortaeformis. O estudo será ampliado com a captura de mais animais para avaliar a ocorrência de outros helmintos, se esta alta prevalência para T. retortaeformis permanece e para permitir avaliar a bundancia e intensidade dos parasitos. Este trabalho apresenta a primeira citação de $T$. retortaeformis parasitando L.europaeus no sul do Brasil.

Palavras-chave: Helmintos. Lebre europeia. Mamíferos exóticos. Sul do Brasil.

\footnotetext{
${ }^{1}$ Discentes de Doutorado, Programa de Pós-Graduação em Parasitologia, Universidade Federal de Pelotas, UFPel, Pelotas, RS, Brasil. E-mail: lauramariajorgedefariasantos@gmail.com; marianammendes@hotmail.com; pliniolega@gmail.com

${ }^{2}$ Discente de Doutorado, Programa de Pós-Graduação em Veterinária, UFPel, Pelotas, RS, Brasil. E-mail: fcoliveiravet@gmail.com

${ }^{3}$ Prof $^{\mathrm{a}} \mathrm{Dr}^{\mathrm{a}}$, Departamento de Microbiologia e Parasitologia, Instituto de Biologia, UFPel, Pelotas, Brasil. E-mail: naraameliafarias@, gmail.com

${ }^{4}$ Prof. Dr., Programa de Pós-Graduação em Parasitologia/Laboratório Regional de Diagnóstico, FAVET, UFPel, Pelotas, RS, Brasil. E-mail: jeronimo.ruas@gmail.com

* Author for correspondence
} 
European hare (Lepus europaeus) is a mammal of the order Lagomorpha and its natural range covers most of Europe except for Ireland, northeastern Great Britain, and a large part of the Iberian and Scandinavian peninsulas. In South America, the hare was introduced for hunting purposes in Argentina and Uruguay in early $20^{\text {th }}$ century (BONINO et al., 2010). Grigera and Rapoport (1983) found that the hare was restricted to the states of Rio Grande do Sul and Santa Catarina in the south ofBrazil; however, the hares' range expanded particularly toward the north of the country, invading the whole state of Paraná and the western part of Sao Paulo and Minas Gerais (BONINO et al., 2010; COSTA; FERNANDES, 2010). The dispersal rates varied between 10 and $37 \mathrm{~km}$ a year. The increase in population size may be caused by the reduction of potential predators due to hunting pressure, road kill, and habitat loss. If not properly managed, this exotic species has the potential to cause extensive damage to native wildlife, habitat, and agricultural resources. The European hare competes for food and habitat with Sylvilagus brasiliensis (Linnaeus,1758), a native medium-sized rabbit (COSTA; FERNANDES, 2010). Although the number of hunters has declined due to the outlawing of commercial and game hunting in Brazil, subsistence hunting of $h$ are by rural communities in Rio Grande do Sul, Brazil is still reported (LOURIVAL; FONSECA, 1997).

Authorized hunters killed seven hare (Instituto Chico Mendes de Conservação da BiodiversidadeICMBIOn ${ }^{\circ} 28810-1$ ) in Rio Grande do Sul (Southern Brazil). The collected animals were placed in individual plastic bags in coolers and transported to the Laboratory of Wild-Animal Parasitology of the Federal University of Pelotas, where they were necropsied and weighed. The body condition and nutritional status were determined after the examination of kidney fat quantity (BANKS et al., 1999). The gastrointestinal tracts of the seven $L$. europaeus were then removed, the organs opened, and washed in a106- $\mu \mathrm{m}$ mesh sieve. Each organ was examined under a stereomicroscope, and its contents washed in order to collect any helminths. The nematodes found were fixed in ethanol (70\%), clarified with Aman's lactophenol for identification in accordance with Allan et al. (1999) and Pinto (2004) and then photographed under an Olympus BX 41 microscope with an adapted camera system.

Six out of seven L. europaeus were parasitized (85.7\%) by T. retortaeformis, which were found in the small intestines (Figure A-D). Among these parasites, 34 were males and 60 were females. Reports on endoparasites in hares are sporadic (especially recently), with none from southern Brazil. The European hare was found naturally infected with T.retortaeformis in many countries in Europe (BORDES et al., 2007; CHROUST et al., 2012; LUKEŠOVÁ et al., 2012; DIAKOU et al., 2014). In Chile (South America), 60\% of hares found were naturally infected with T.retortaeformis (GONZÁLEZ-ACUÑA et al., 2005). In southern Brazil, Santiago et al. (1978) found Trichostrongylus sp., $T$.colubriformis, Ostertagia sp., and Haemonchus sp. in hare and $T$. retortaeformis in Cavia aperea. These two hosts share the same environment and food resources. The four known life cycles of Trichostrongylus species in ruminants present no significant difference compared with that of $T$. retortaeformis, exceptin the duration of the prepatent period. The parasite also has a tendency to migrate into the intestinal mucosa during the initial establishment phase, causing catarrhal enteritis, which maybe mild enough to avoid clinica ldetection (AUDEBERT et al., 2003; WIBBELT; FRÖLICH, 2005). These similarities in the lifecycles confirm the previously formulated hypotheses on the relationship between the parasites of the two host groups. In rabbits, infection rates vary seasonally and are influenced by the rabbit's age. Higherbur dens are apparent in younger rabbits in summer months. Infection rate is also expected to increase in spring and summer as a result of immunosuppression associated with raised testosterone levels in males, immune systems of juveniles, and a combination of the periparturient rise in females sharing for aging 
habitat with juveniles (CATTADORI et al., 2005; CORNELL et al., 2008). Our restricted number of individuals captured does not permit either intensity or prevalence estimates. We aim capture more hares to evaluate the consistency in prevalence rate and the intensity and abundance of $T$. retortaeformis along with other helminthes found. In this work, we evaluated the presence of $T$.retortaeformis infection in hares from the southern area of Brazil, in the state of Rio Grande do Sul.

Figure 1. Trichostrongylus retortaeformis: (A) Posterior portion of male, the spicules are short, large, curved with two thin offshoots (arrow) (B) Posterior portion of female (C) Anterior portion of female. Posterior portion of female with eggs in utero; (12).

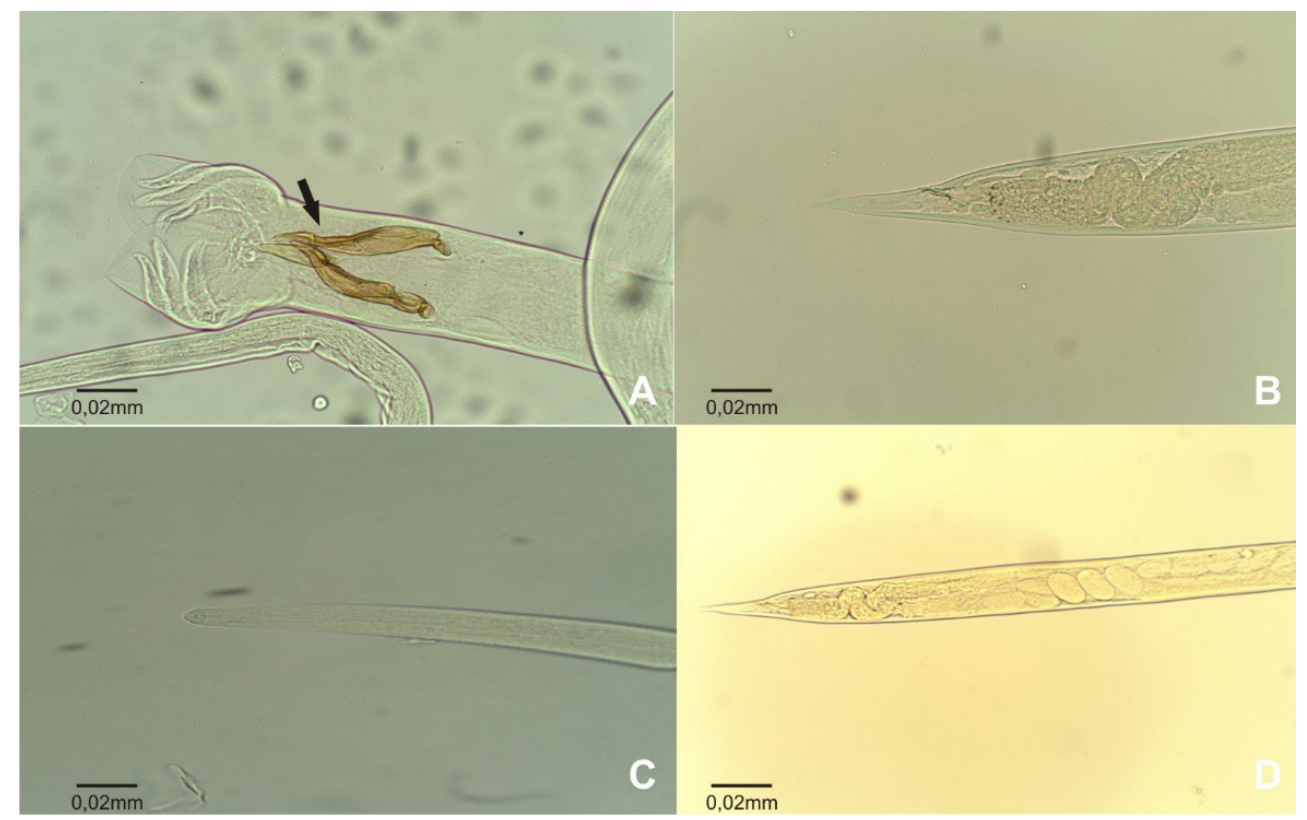

To our knowledge, this is the first study that has confirmed the presence of Trichostrongylus retortaeformis parasitizing Lepus europaeus in southern Brazil. Additional data is required to expand the knowledge.

\section{References}

ALLAN, J. C.; CRAIG, P. S.; SHERINGTON, J.; ROGAN, M. T.; STOREY, D. M.; HEATH, S.; IBALL, K. Helminth parasites of wild rabbit Oryctologus cuniculus Yorkshire, UK. Journal of Helminthology, Cambridge, v. 73, n. 4, p. 289-294, 1999.

AUDEBERT,F.; VUONG,P.N.;DURETTE-DESSET, M. C. Intestinal migrations of Trichostrongylusretortaeformis (Trichostrongylina, Trichostrongylidea) in the rabbit. Veterinary Parasitolology, Amsterdam, v. 112, n. 1-2, p. 131-146, 2003.
BANKS, P. B.; HUME, I. D.; CROWE, O. Behavioural, morphological and dietary response of rabbit to predation risk foxes. Oikos, Lund, v. 85, n. 2, p. 247256, 1999.

BONINO, N.; COSSÍOS, D.; MENEGHETI, J. Dispersal of the European hare, Lepus europaeus in South America. Folia Zoologica, Brno, v. 59, n. 1, p. 9-15, 2010.

BORDES, F.; LANGAND, J.; FELIU, C.; MORAND, $\mathrm{S}$. Helminth communities of an introduced hare Lepus granatensis) and a native hare (Lepus europaeus) in southern France. Journal of Wildlife Diseases, Lawrence, v.43, p.747-75, p. 741-751, 2007.

CATTADORI, I. M.; BOAG, B.; BJØRNSTAD, O. N.; CORNELL, S. J.; HUDSON, P. J. Immuno-epidemiology and peak shift in a seasonal host-nematode system. Proceedings of the Royal Scociety B: Bological Sciences, London, v. 272, n. 1577, p. 1167-1169, 2005. 
CHROUST, K.; VODNANSKY, M.; PIKULA, J. Parasite load of European brown hares in Austria and the Czech Republic. Veterinarni Medicina, Prague, v. 57, n. 10, p. 551-558, 2012.

CORNELL, S. J.; BJORNSTAD, O. N.; CATTADORI, I. M.; BOAG, B.; HUDSON, P. J. Seasonality, cohortdependence and the development of immunity in a natural host-nematode system. Proceedings of the Royal Scociety B: Bological Sciences, London, v. 272, n. 1577, p. 1167-1169, 2008.

COSTA, M. D.; FERNANDES, F. A. B. Primeiro registro de Lepus europaeus Pall as, 1778 (Mammalia, Lagomorpha, Leporidae) no sul do Estado de Minas Gerais e uma síntese dos registros conhecidos para o sudeste do Brasil. Revista Brasileira de Zoociências, Juiz de Fora, v. 12, n. 3, p. 311-314, 2010.

DIAKOU, A.; SOKOS, C.; PAPADOPOULOS, E. Endoparasites found in European Brown hares (Lepus europaeus) hunted in Macedonia, Greece. Helminthologia, Berlin,v. 51, n. 4, p. 345-351, 2014.

GONZÁLEZ-ACUÑA, D.; REBOLLEDO, P.; SKEWES, O.; MORENO, L.; CASTRO, D. Parásitos de La liebre (Lepus europaeusPallas, 1778): estúdio em dos zonas geográficas de Chile. Parasitologia Latinoamericana, Santiago, v. 60, p. 174-177, 2005.

GRIGERA, D. E.; RAPOPORT, E. H. Status and distribution of the European Hare in South America. Journal of Mammalogy, Lawrence, v. 64, n. 1, p. 163$166,1983$.
LOURIVAL, R. F. F.; FONSECA, G. A. B. Análise de sustentabilidade do modelo de caça tradicional, no Pantanal da Nhecolândia, Corumbá, MS. In: VALLADARES-PADUA, C.; BODMER, R. E.; CULLEN JÚNIOR, L. (Org.). Manejo e conservação de vida silvestre no Brasil. Brasília: CNPq; Belém: Sociedade Civil Mamirauá, 1997. p. 123-172.

LUKEŠOVÁ, D.; LANGROVÁ, I.; VADLEJCH, J.; JANKOVSKÁ, I.; HLAVA, J.; VÁLEK, P.; ČADKOVÁ, Z. Endoparasites in European hares (Lepus europaeus) under gamekeeping conditions in the Czech Republic. Helminthologia, Berlin, v. 49, n. 3, p. 159-163, 2012.

PINTO, R. M.; GOMES, D. C.; MENEZES, R. C.; GOMES, C. T.; NORONHA, D. Helminths of rabbits (Lagomorpha, Leporidae) deposited in the helminthological collection of the Oswaldo Cruz Institute. Revista Brasileira de Zoologia, Curitiba, v. 21, n. 3, p. 599-604, 2004.

SANTIAGO, M. A. M.; PEREIRA, R. de S.; COSTA, U. C.; BENEVENGA, S. Inquérito sobre helmintos em animais silvestres do Rio Grande do Sul. I. Lebre e Preá. Revista do Centro de Ciências Rurais, Santa Maria, v. 8, n. 4, p. 303-305, 1978.

WIBBELT, G.; FRÖLICH, K. Infectious diseases in european brown hare (Lepus europaeus). Wildlife Biolology in Practice, Aveiro, v. 1, n. 1, p. 86-93, 2005. 